\title{
APLIKASI LEAN CONSTRUCTION UNTUK MENGIDENTIFIKASI PEMBOROSAN PADA PROSES LOGISTIK PROYEK
}

\author{
Sri Sugiantari ${ }^{1}$, I G. A. Adnyana Putera $^{2}$, dan Gd. Astawa Diputra ${ }^{2}$
}

\begin{abstract}
Abstrak : Proses logistik proyek konstruksi menyembunyikan aktivitas-aktivitas yang tidak bernilai tambah yang sulit dihindari, menambah waktu tenggang yang berdampak pada keterlambatan penyelesaian proyek, serta meningkatkan biaya produksi yang akan mengurangi profit.

Pengumpulan data dengan kuisioner dilakukan di 22 kontraktor dengan kualifikasi besar di wilayah Denpasar dengan 3 responden di masing-masing kontraktor, sehingga diperoleh 66 responden ahli. Pengumpulan data dengan kuisioner dilakukan dalam 2 tahap. Tahap pertama, kuisioner untuk mengidentifikasi pemborosan. Tahap kedua, kuisioner untuk mengetahui penyebab pemborosan. Observasi di lapangan bertujuan untuk membuat value stream mapping (peta aliran nilai) proses logistik proyek konstruksi.

Ada 7 aktivitas pemborosan yang sering terjadi: Inspeksi lapangan, pembelian satu jenis barang pada pemasok yang berbeda, menunggu instruksi kerja dari owner, keterlambatan pengiriman material, keperluan persetujuan atau tanda tangan tambahan, keperluan klarifikasi tindakan, dan menunggu instruksi kerja dari atasan. Penyebab dari masing-masing pemborosan tersebut, yaitu: karena pekerja yang diinspeksi kurang terampil, kualitas barang yang diberikan pemasok buruk, prosedur dari owner yang mengharuskan pekerja menunggu instruksi sebelum bekerja, proses pengangkutan dan distribusi yang terlalu lambat, birokrasi yang berbelit-belit, dan informasi yang tidak jelas. Dan dari hasil observasi didapatkan ada aktivitas tidak bernilai tambah yang terjadi sepanjang value stream logistik proyek konstruksi, antara lain, menunggu persetujuan atasan, transportasi, menunggu proses order yang masih dikerjakan secara manual dan cacat produk pada saat seleksi material. Untuk mengurangi pemborosan tersebut perlu menyederhanakan proses, membuat prosedur operasi standar, memberikan pelatihan yang cukup kepada tenaga kerja, menggunakan teknologi informasi, mengadakan kontrak jangka panjang dengan pemasok dan pelanggan internal.
\end{abstract}

Kata kunci: Pemborosan, Logistik Proyek Konstruksi, Lean Construction, Peta Aliran Nilai

\section{APPLICATION OF LEAN CONSTRUCTION TO IDENTIFY THE WASTING ON PROJECT LOGISTICS PROCESS}

\begin{abstract}
Construction logistics process hides some non value added activities which are difficult to avoid, those activities have extended leading time which are not only cause the delay of the project completion, but also spend more production expenses that effect to the profit itself.

Data rising by questionnaire is conducted in 22 qualified contractors around Denpasar with 3 respondents in each contractor. Data raising by questionnaire is done in 2 stages, first stage is questionnaire which identify wastes. Second stage are questionnaire which determine waste causes. Field observation is aimed to create a value steam mapping of construction logistic process.

It had been found 7 types of wasting which often occurs. They are the field inspection, the purchase of one type material in different suppliers, awaiting the instruction of the owner, the delay of the material transportation, the purpose of approval or additional signature, clarification needs, awaiting the instruction of the superior. Afterwards, the cause of each wasting, namely the workers inspected are less skilled, the bad quality of goods given by the suppliers, the owner procedures which require workers await the instruction before working, material loading-unloading and distribution process is too slow, a complicated bureaucratic system and unclear information. And from the observation, it is obtained that there are some non-added activities occurred throughout the value stream of the construction project logistics, among them awaiting the approval of the supervisors, transportation, awaiting the order process which is still done manually and product defects during the material selection. As a wasting reduction, it is necessary to simplify the process, create a standard operation procedure, provide enough training to the workers so they are more independent, use an information technology to ease the delivery of the report, hold a long-term contracts with the suppliers and the internal customers.
\end{abstract}

Keyword: Waste, construction project logistics, lean construction, value stream mapping

\footnotetext{
${ }^{1}$ Mahasiswa Program Studi Magister Teknik Sipil, Program Pascasarjana, Universitas Udayana, Denpasar

${ }^{2}$ Staf Pengajar Program Studi Magister Teknik Sipil, Program Pascasarjana, Universitas Udayana, Denpasar
} 


\section{PENDAHULUAN}

\section{Latar Belakang}

Melalui wawancara awal dengan pelaku jasa konstruksi di Denpasar, masalah umum yang sering terjadi pada proses logistik proyek konstruksi di Bali khususnya di Denpasar antara lain, material yang datang terlambat sehingga membuat para pekerja menunggu, seringnya kehilangan material baik itu karena masalah keamanan atau kesalahan penyimpanan sehingga membuat material tersebut cacat dan tidak bisa dipakai lagi, banyaknya pergerakan yang dilakukan pekerja saat memindahkan material karena tata letak yang buruk, banyaknya jumlah supplier yang menyebabkan inkonsistensi mutu material hingga banyaknya dokumen-dokumen yang tercecer yang berhubungan dengan logistik dan inventaris.

\section{Tujuan Penelitian}

Tujuan dari penelitian ini adalah :

1. Jenis pemborosan apa saja yang sering terjadi pada proses logistik proyek konstruksi dan apa penyebabnya?

2. Bagaimana persepsi perusahaan dan praktisi jasa konstruksi di Denpasar tentang prinsip Lean Construction sebagai sebuah pilihan strategis dan filosofi baru dalam dunia konstruksi?

3. Apa saja aktivitas tidak bernilai tambah (non value added activities) terjadi sepanjang value stream pada logistik proyek?

\section{KAJIAN PUSTAKA}

\section{Pendekatan Lean}

Lean adalah suatu upaya terus-menerus untuk menghilangkan pemborosan (waste) dan meningkatkan nilai tambah (value added) produk (barang dan atau jasa) agar memberikan nilai kepada pelanggan (customer value). Tujuan Lean adalah meningkatkan terus-menerus rasio antara nilai tambah terhadap waste (the value-to-waste ratio).

\section{Lean Construction}

Istilah Lean Construction pertama diajukan oleh Koskela (1992) yang berpendapat bahwa industri jasa konstruksi harus bergerak dengan pemikiran Lean untuk meningkatkan filosofi produksi yang ada selama ini. Konsep ini diperlukan ketika konsep produksi Lean untuk manufaktur tidak cocok digunakan pada sifat dan karakteristik proyek konstruksi (Bjönfort dalam Gustavson dan Marzec,2007). Menanggapi keunikan sifat industri ini Koskela,1992 menyimpulkan ada 11 prinsip lean construction, yaitu:

1. Mengurangi aktivitas-aktivitas tak bernilai tambah di setiap tahapan.

2. Meningkatkan nilai akhir melalui pertimbangan sistematis terhadap keinginan pelanggan (owner)

3. Mengurangi ketimpangan (variabilitas)

4. Mengurangi waktu siklus

5. Menyederhanakan dengan meminimalisasi jumlah langkah, bagian-bagian dan hubungan antar aktivitas.

6. Meningkatkan fleksibilitas hasil.

7. Meningkatkan transparansi terhadap proses.

8. Fokus terhadap pengendalian keseluruhan proses.

9. Membangun peningkatan terus-menerus terhadap proses.

10. Menyeimbangkan peningkatan aktivitas aliran dengan aktivitas konversi.

11. Benchmark.

\section{Value Stream Mapping}

Value Stream Mapping (VSM) adalah alat yang biasa digunakan dalam program perbaikan terus-menerus dalam Lean Production untuk membantu memahami dan meningkatkan aliran material dan informasi dalam organisasi. VSM lahir sebagai gambaran ideologi Lean dan menunjukkan keseluruhan proses (Peterka, 2009)

Tujuan utama VSM adalah untuk memperbaiki/meningkatkan proses. Ini dicapai dengan mengarisbawahi area-area pemborosan dalam proses sehingga mempermudah perusahaan untuk menghilangkan pemborosan tersebut. VSM juga mempunyai kuntungan dalam mengkategorikan kegiatan menjadi 3 daerah utama, yaitu: bernilai tambah, tidak bernilai tambah (tetapi diperlukan) dan pemborosan.

\section{Pemborosan}

Pemborosan (waste) dapat didefinisikan sebagai segala aktivitas kerja yang tidak memberikan nilai tambah dalam proses transformasi input menjadi output sepanjang value stream.

Koskela,1992 telah mengidentifikasi pemborosan dalam proses konstruksi seperti:

1. Jumlah cacat

2. Pengerjaan kembali (rework) 
3. Jumlah kesalahan desain/rancangan.

4. Kehilangan

5. Banyaknya perubahan (change order)

6. Biaya Keselamatan/keamanan.

7. Konsumsi material yang berlebih.

Untuk menghilangkan aktivitas tak bernilai tambah ini, perlu untuk mengidentifikasi penyebab atau sumber pemborosan tersebut.

\section{Manajemen Logistik}

Menurut Silva dan Cardoso,1999, dalam dunia jasa konstruksi, logistik bisa dipahami sebagai sebuah proses multidisipliner yang berusaha menjamin pada waktu, biaya dan mutu yang tepat dalam hal:

a. Penyediaan material, penyimpanan, pemrosesan dan pengerjaan.

b. Pengadaan orang-orang

c. Pengontrolan jadwal

d. Lokasi peralatan dan infrastruktur lapangan

e. Manajemen aliran material di lapangan

f. Manajemen informasi yang berhubungan dengan semua aliran fisik dan pelayanan

Fungsi logistik di dalam jasa konstruksi bisa dibagi menjadi Logistik Pasokan (Supply Logistic) dan Logistik Lapangan (Site Logistic).

\section{METODOLOGI PENELITIAN}

\section{Lokasi Penelitian}

Penelitian ini mengambil lokasi di kontraktor-kontraktor dengan kualifikasi Besar wilayah kota Denpasar dan sekitarnya. Untuk pengumpulan data dengan kuisioner akan dilakukan di 22 kontraktor dengan kualifikasi Besar di wilayah Denpasar dengan 3 responden di masing-masing kontraktor yang diisi oleh tiga dari lima jabatan yang ditentukan,yaitu: manajer proyek, site manager, quantity surveyor, manajer logistik dan direktur.

Sedangkan lokasi observasi akan dilakukan pada 2 proyek berbeda yang dilakukan oleh kontraktor yang berbeda di wilayah Denpasar, dimana salah satu kontraktor sudah tersertifikasi ISO 9000 dan satunya lagi belum tersertifikasi.

\section{Populasi dan Sampel}

Populasi untuk penelitian ini adalah semua kontraktor di Denpasar dengan spesialisasi atau bidang keahlian bangunan / gedung menurut data GAPENSI 2008 Denpasar.
Dari daftar yang terdapat di GAPENSI Denpasar periode Tahun 2008 terdapat 41 kontraktor bangunan gedung dengan kualifikasi Gred 5 sampai Gred 7 yang ada di Denpasar dan bound of error yang diharapkan sebesar 0,15 .

Sehingga besarnya sampel berdasarkan rumus yaitu:

$$
\begin{aligned}
& D=\frac{0,15^{2}}{4}=0,005625 \\
& n=\frac{41 \times 0,5(1-0,5)}{(41-1) \times 0,005625+0,5(1-0,5)}=21,5 \approx 22 \\
& \text { sampel }
\end{aligned}
$$

\section{Pengumpulan Data}

Pengumpulan data dengan kuisioner dilakukan dalam 2 tahap:

a. Kuisioner pertama yang selanjutnya disebut "Kuisioner Identifikasi Pemborosan" untuk mengidentifikasi tipetipe pemborosan yang sering terjadi di dalam logistik proyek.

b. Kuisioner kedua yang selanjutnya disebut "Kusioner Penyebab Pemborosan" yang menghadirkan penyebab pemborosan yang krusial dari hasil analisis kuisioner identifikasi pemborosan.

c. Kuisioner ketiga yang selanjutnya disebut "Kuisioner Penerimaan LC dan Kaizen". digunakan untuk melihat apakah mereka bisa menerima prinsip utama dari Lean Construction dan Kaizen ini dan mengimplementasikannya.

Observasi di lapangan bertujuan untuk mengetahui kondisi sebenarnya mengenai aliran proses logistik pada suatu proyek. Proyek yang diteliti diambil pada 2 perusahaan kontraktor yang berbeda dimana salah satu dari perusahaan tersebut telah menerapkan ISO 9000 dan satunya lagi tidak. Pertimbangannya perusahaan yang telah tersertifikasi ISO 9000 sudah mempunyai prosedur dan standar kerja terhadap berbagai proses.

\section{Pengolahan Data}

Data kuisioner diolah dengan pengukuran statistik. Kuisioner identifikasi pemborosan diolah dengan pengukuran statistik frekuensi untuk mengetahui tipe dan penyebab pemborosan yang sering terjadi, diambil dari variabel yang nilai rata-rata (Mean) $\geq 4,00$.

Kuisioner penyebab pemborosan diolah dengan analisis non-parametrik karena data bersifat nominal. Pada tahap statistik deskriptif digunakan modus untuk menggambarkan ukuran pusat data non- 
parametrik. Selanjutnya pada tahapan statistik inferensia atau statistik induktif digunakan uji beda (uji hipotesis) dan uji normalitas data dengan Kolmogorov-Smirnov untuk mengambil keputusan apakah data dari sampel yang ada sudah cukup kuat untuk menggambarkan populasinya. Semua perhitungan statistik dihitung dengan komputer menggunakan program berbasis statistik, yaitu program SPSS.

Kuisioner penerimaan LC dan Kaizen dianalisis dengan cara yang sama dengan kuisiner kedua karena data yang tersaji bukanlah data interval atau rasio sehingga statistik non-parametrik tetap menjadi pilihan untuk mendiskripsikan data dan mengambil keputusan. Perbedaannya untuk mendeskripsikan data digunakan median karena data bersifat ordinal untuk mengetahui ukuran pusat datanya. Selanjutnya untuk menginduksi data digunakan uji hipotesis dengan uji Run dan uji normalitas data dengan Kolmogorov-Smirnov untuk menguji apakah benar pernyataan bahwa praktisi jasa konstruksi di Denpasar menerima dan menerapkan prinsip-prinsip Kaizen sebagai bagian dari Lean Construction.

Data-data yang dikumpulkan dalam studi kasus atau observasi di lapangan seperti data: waktu siklus dan jumlah operator digunakan untuk membuat value stream map proses logistik proyek. Setelah itu untuk membuat peta aliran nilai masa depan (Future Value Stream Map) digunakan teknik brainstorming untuk melihat aktivitas-aktivitas tak bernilai tambah sepanjang value stream itu dan membandingkannya pada dua kontraktor yang berbeda.

\section{HASIL DAN PEMBAHASAN}

Survai dilakukan kepada 22 Kontraktor Grade 5 sampai Grade 7 dengan spesifikasi bidang Bangunan dan Gedung yang terdaftar di daftar Gapensi Bali 2008 untuk wilayah Denpasar. Masing-masing kontraktor diberi 3 buah kuisioner yang sama yang diisi oleh tiga jabatan berbeda dari lima pilihan jabatan yang disediakan, yaitu: Direktur, Site Manager, Project Manager, Manajer Logistik dan Quantity Surveyor. Berdasarkan analisis frekuensi dengan SPSS 13 didapat bahwa kuisioner paling banyak diisi oleh Manajer logistik yaitu sebesar 31,8\%. Site Manager, Project Manager dan Quantitiy Surveyor jumlahnya hampir imbang yaitu berturut-turut $19,7 \%, 18,2 \%$ dan 18,2\%. Direktur merupakan responden yang paling sedikit dalam mengisi kuisioner ini, yaitu $12,1 \%$.

\section{Hasil Analisis Kuisioner Identifikasi Pemborosan}

Pada tahap ini,survai dilakukan dua kali. Survai pertama atau survai pendahuluan dilakukan pada 8 kontraktor untuk menguji validitas data. Hasil uji validitas dengan Corrected Item-Total Correlation dan dengan korelasi Pearson,didapat ada variable yang tidak valid,yakni: Material yang lama berada di lapangan dan Pekerja yang berisitirahat melebihi waktu yang ditentukan. Kedua variable tersebut dihilangkan, dan dilanjutkan dengan survai kedua di 14 kontraktor yang tersisa.

Pada survai kedua semua item variabel yang diujikan valid dan menunjukkan korelasi yang positif.

Analisis rata-rata digunakan untuk melihat tingkat intensitas pemborosan masingmasing variable. Proses analisa data terhadap 66 responden peneliti lakukan dengan bantuan software SPSS yang tabel hasinya dapat dilihat sebagai berikut:

\begin{tabular}{|c|c|c|c|}
\hline No & Variabel & Mean & $\begin{array}{l}\text { Std. } \\
\text { Deviat } \\
\text { ion }\end{array}$ \\
\hline 1 & $\begin{array}{l}\text { Inspeksi di } \\
\text { lapangan }\end{array}$ & 3,02 & 1,641 \\
\hline 2 & $\begin{array}{l}\text { Pembelian } 1 \text { jenis } \\
\text { barang pada } \\
\text { pemasok yang } \\
\text { berbeda }\end{array}$ & 2,89 & 1,302 \\
\hline 3 & $\begin{array}{l}\text { Menunggu instruksi } \\
\text { kerja dari owner }\end{array}$ & 2,79 & 1,000 \\
\hline 4 & $\begin{array}{l}\text { Keterlambatan } \\
\text { pengiriman } \\
\text { material }\end{array}$ & 2,62 & 1,078 \\
\hline 5 & $\begin{array}{l}\text { Keperluan } \\
\text { persetujuan atau } \\
\text { tandatangan } \\
\text { tambahan }\end{array}$ & 2,59 & 1,176 \\
\hline 6 & $\begin{array}{l}\text { Keperluan } \\
\text { klarifikasi terhadap } \\
\text { suatu tindakan }\end{array}$ & 2,55 & 1,070 \\
\hline 7 & $\begin{array}{l}\text { Menunggu instruksi } \\
\text { kerja dari atasan }\end{array}$ & 2,53 & 1,417 \\
\hline 8 & $\begin{array}{l}\text { Waktu } \\
\text { pengangkutan yang } \\
\text { lama }\end{array}$ & 2,35 & 1,074 \\
\hline 9 & $\begin{array}{l}\text { Keterlambatan } \\
\text { pengiriman } \\
\text { peralatan }\end{array}$ & 2,32 & 0,788 \\
\hline 10 & $\begin{array}{l}\text { Banyaknya Work In } \\
\text { Process }\end{array}$ & 2,27 & 0,969 \\
\hline
\end{tabular}




\begin{tabular}{|c|c|c|c|}
\hline 11 & $\begin{array}{l}\text { Menunggu } \\
\text { informasi yang } \\
\text { diperlukan }\end{array}$ & 2,26 & 0,829 \\
\hline 12 & $\begin{array}{l}\text { Lokasi basecamp } \\
\text { dan lokasi } \\
\text { pekerjaan yang } \\
\text { berjauhan }\end{array}$ & 2,21 & 0,713 \\
\hline 13 & $\begin{array}{l}\text { Menunggu } \\
\text { dokumen yang } \\
\text { diperlukan }\end{array}$ & 2,17 & 0,796 \\
\hline 14 & $\begin{array}{l}\text { Mencari } \\
\text { perkakas,material, } \\
\text { peralatan dan } \\
\text { gambar di lapangan }\end{array}$ & 2,17 & 1,104 \\
\hline 15 & $\begin{array}{l}\text { Duplikasi dokumen } \\
\text { yang berhubungan } \\
\text { dengan proses } \\
\text { konstruksi }\end{array}$ & 2,15 & 1,231 \\
\hline 16 & $\begin{array}{l}\text { Duplikasi dokumen } \\
\text { yang berhubungan } \\
\text { dengan inventory }\end{array}$ & 2,15 & 1,026 \\
\hline 17 & $\begin{array}{l}\text { Formulir, cetakan } \\
\text { dan kertas yang } \\
\text { berlebih }\end{array}$ & 2,15 & 1,041 \\
\hline 18 & $\begin{array}{l}\text { Banyaknya } \\
\text { Material di gudang } \\
\text { yang belum } \\
\text { digunakan }\end{array}$ & 2,14 & 0,762 \\
\hline 19 & $\begin{array}{l}\text { Menunggu } \\
\text { ketersediaan } \\
\text { pekerja/buruh }\end{array}$ & 2,11 & 0,747 \\
\hline 20 & $\begin{array}{l}\text { Material yang rusak } \\
\text { karena kesalahan } \\
\text { pemasok }\end{array}$ & 2,08 & 0,829 \\
\hline 21 & $\begin{array}{l}\text { Material yang } \\
\text { berlebih di } \\
\text { lapangan }\end{array}$ & 2,03 & 0,679 \\
\hline 22 & $\begin{array}{l}\text { Mencari } \\
\text { berkas,laporan atau } \\
\text { gambar }\end{array}$ & 2,03 & 1,081 \\
\hline 23 & $\begin{array}{l}\text { Peralatan yang } \\
\text { rusak karena salah } \\
\text { penyimpanan }\end{array}$ & 1,98 & 0,794 \\
\hline 24 & $\begin{array}{l}\text { Banyaknya } \\
\text { perlengkapan yang } \\
\text { tak terpakai }\end{array}$ & 1,95 & 0,968 \\
\hline 25 & $\begin{array}{l}\text { Waktu bongkar } \\
\text { muat yang lama }\end{array}$ & 1,95 & 0,711 \\
\hline 26 & $\begin{array}{l}\text { Negosiasi yang } \\
\text { berulang dengan } \\
\text { pemasok yang sama }\end{array}$ & 1,94 & 0,943 \\
\hline 27 & $\begin{array}{l}\text { Material yang rusak } \\
\text { karena salah } \\
\text { penyimpanan }\end{array}$ & 1,91 & 0,673 \\
\hline 28 & $\begin{array}{l}\text { Duplikasi dalam } \\
\text { pengisian formulir }\end{array}$ & 1,89 & 0,930 \\
\hline
\end{tabular}

\begin{tabular}{|c|c|c|c|}
\hline 29 & $\begin{array}{l}\text { Duplikasi dokumen } \\
\text { yang berhubungan } \\
\text { dengan pembelian }\end{array}$ & 1,88 & 1,045 \\
\hline 30 & $\begin{array}{l}\text { Terjadi kerusakan } \\
\text { yang menyebabkan } \\
\text { hasil pekerjaan } \\
\text { harus dibongkar/ } \\
\text { Diperbaiki }\end{array}$ & 1,86 & 0,630 \\
\hline 31 & $\begin{array}{l}\text { Matrerial yang } \\
\text { rusak karena salah } \\
\text { dalam memproses }\end{array}$ & 1,85 & 0,707 \\
\hline 32 & $\begin{array}{l}\text { Banyaknya } \\
\text { pergerakan pekerja } \\
\text { yang tidak efektif }\end{array}$ & 1,82 & 0,910 \\
\hline 33 & $\begin{array}{l}\text { Material yang } \\
\text { terlalu sering } \\
\text { dipindahkan karena } \\
\text { berbagai alasan }\end{array}$ & 1,76 & 0,766 \\
\hline 34 & $\begin{array}{l}\text { Kesalahan } \\
\text { perencanaan } \\
\text { pasokan material }\end{array}$ & 1,74 & 0,664 \\
\hline 35 & $\begin{array}{l}\text { Peralatan yang } \\
\text { rusak karena salah } \\
\text { pengoperasian }\end{array}$ & 1,74 & 0,686 \\
\hline 36 & $\begin{array}{l}\text { Pengiriman } \\
\text { material yang lebih } \\
\text { cepat dari yang } \\
\text { dibutuhkan }\end{array}$ & 1,73 & 0,795 \\
\hline 37 & $\begin{array}{l}\text { Kelebihan } \\
\text { pemesanan material }\end{array}$ & 1,67 & 0,709 \\
\hline 38 & $\begin{array}{l}\text { Kesalahan } \\
\text { perencanaan } \\
\text { pasokan tenaga } \\
\text { kerja }\end{array}$ & 1,64 & 0,694 \\
\hline 39 & $\begin{array}{l}\text { Suku cadang yang } \\
\text { berlebih }\end{array}$ & 1,59 & 0,679 \\
\hline 40 & $\begin{array}{l}\text { Metode kerja yang } \\
\text { salah }\end{array}$ & 1,48 & 0,638 \\
\hline & Valid N (listwise) & & \\
\hline
\end{tabular}

Berdasarkan hasil analisis yang terlihat pada Tabel diatas, tidak ada variabel pemborosan yang mempunyai rata-rata diatas atau sama dengan 4,00. Oleh karena itu untuk melanjutkan penelitian dan mencari penyebab pemborosan, diambil variabel yang mempunyai rata-rata diatas atau sama dengan 2,50 dengan pertimbangan bahwa variabelvariabel ini dapat mewakilkan pemborosan yang cukup sering terjadi pada jasa konstruksi di Denpasar. Didapatkan ada tujuh pemborosan yang sering terjadi pada jasa konstruksi di Denpasar, yaitu:

1. Inspeksi di Lapangan

2. Pembelian satu jenis barang pada pemasok yang berbeda

3. Menunggu instruksi kerja dari owner 
4. Keterlambatan pengiriman material

5. Keperluan persetujuan atau tanda tangan tambahan

6. Keperluan klarifikasi terhadap suatu tindakan

7. Menunggu instruksi kerja dari atasan

\section{Hasil Analisis Kuisioner Penyebab Pemborosan}

Analisa kuisioner kedua bertujuan untuk mengetahui penyebab dari pemborosan yang sering terjadi pada jasa konstruksi di Denpasar.

Jenis data pada kuisioner kedua merupakan data nominal, oleh karena itu statistik yang relevan adalah modus. Dari pengolahan data menggunakan SPSS 13.0, didapat modus masing-masing variabel yang sekaligus menjelaskan penyebab paling sering terjadinya pemborosan tersebut adalah sebagai berikut:

1. Inspeksi di Lapangan disebabkan karena pekerja yang kurang terampil dengan persentase sebesar $45,5 \%$

2. Pembelian satu jenis barang pada pemasok yang berbeda disebabkan karena kualitas barang yang diberikan pemasok buruk dengan nilai persentase $53 \%$

3. Menunggu instruksi kerja dari owner karena prosedur dari owner yang mengharuskan demikian dengan persentase frekuensi $54,5 \%$

4. Keterlambatan pengiriman material karena proses pengangkutan dan distribusi material yang terlalu lama dengan persentase $39,4 \%$

5. Keperluan persetujuan/tanda tangan tambahan disebabkan karena birokrasi sistem sehingga prosedur kerja/proses lainnya berbelit-belit dengan persentase 90,9\%.

6. Keperluan klarifikasi terhadap suatu tindakan karena informasi yang diberikan tidak jelas dengan persentase $45,5 \%$.

7. Menunggu instruksi kerja dari atasan juga lebih banyak karena prosedur kerja dari perusahaan yang mengharuskan demikian dengan persentase $74,2 \%$.

\section{Hasil Analisis Kuisioner Penerimaan LC dan Kaizen}

Kuisioner penerimaan LC dan Kaizen berisi pertanyaan-pertanyaan yang dibagi menjadi 5 kelompok faktor:

1. Aktivitas yang tidak bernilai tambah atau pemborosan harus dihilangkan.
2. Kesediaan perusahaan untuk menghilangkan pemborosan tersebut

3. Perlunya pertimbangan sistematis terhadap kebutuhan pelanggan.

4. Mentalitas terhadap perbaikan terusmenerus (Kaizen)

5. Kesediaan perusahaan untuk melakukan perbaikan terus-menerus (Kaizen).

Masing-masing faktor tersebutlah yang akan diuji hipotesis untuk melihat sikap responden terhadap masing-masing faktor tersebut.

\section{Uji Normalitas dan Uji Hipotesis}

Uji normalitas faktor-faktor tersebut diuji dengan metode Kolmogorov-Smirnov dengan proses pengambilan keputusan sebagai berikut:

$\mathrm{H}_{0}=$ data respon responden terhadap faktor 1 berdistribusi normal

$\mathrm{H}_{1}=$ data repon responden terhadap faktor 1 tidak berdistribusi normal

Dasar pengambil keputusan:

1. Dengan membandingkan KolmogorovSmirnov hitung dengan KolmogorovSmirnov tabel:

- Jika Kolmogorov-Smirnov hitung < Kolmogorov-Smirnov tabel, $\mathrm{H}_{0}$ diterima.

- Jika Kolmogorov-Smirnov hitung > Kolmogorov-Smirnov tabel, $\mathrm{H}_{0}$ ditolak.

2. Dengan melihat angka probabilitas, dengan ketentuan:

- Probabilitas > 0,025 maka $\mathrm{H}_{0}$ diterima

- Probabilitas < 0,025 maka $\mathrm{H}_{0}$ ditolak

Hasil analisa dengan SPSS didapat uji normalitas untuk masing-masing faktor tersebut menunjukkan bahwa distribusi data tidak mengikuti distribusi data normal. Kondisi ini yang membuat data tidak bisa diperlakukan menggunakan statistik parametrik.

Kemudian uji hipotesis dilakukan untuk melengkapi tahapan statistik induksi yakni untuk mengambil keputusan apakah responden menerima masing-masing faktor tersebut. Uji hipotesis dilakukan dengan uji Runs, dimana nilai cut pointnya adalah nilai median dengan pertimbangan bahwa responden akan berespon positif terhadap masing-masing kategori variabel sesuai dengan yang diharapkan dan sampel diambil secara acak sehingga dapat mewakili respon populasi terhadap masingmasing faktor. 
Tabel hasil uji Runs Faktor 1

\begin{tabular}{|l|r|}
\hline & $\begin{array}{c}\text { Asymp. } \\
\text { Sig. }(2- \\
\text { tailed })\end{array}$ \\
\hline $\begin{array}{l}\text { Sebagaian besar pemborosan } \\
\text { tersebut menghabiskan biaya yang } \\
\text { signifikan } \\
\text { Sebagaian besar pemborosan } \\
\text { tersebut menghabiskan/mengulur } \\
\text { waktu penyelesaian }\end{array}$ & 0,903 \\
$\begin{array}{l}\text { Hampir semua peborosan tersebut } \\
\text { bisa dihilangkan }\end{array}$ & 0,807 \\
$\begin{array}{l}\text { Semua pemborosan tersebut harus } \\
\text { dihilangkan }\end{array}$ & 0,057 \\
$\begin{array}{l}\text { Pemborosan tersebut tidak } \\
\text { memberi nilai tambah terhadap } \\
\text { hasil akhir produk }\end{array}$ & 0,752 \\
$\begin{array}{l}\text { Sebagaian pemborosan tersebut } \\
\text { bisa dikendalikan }\end{array}$ & 0,029 \\
$\begin{array}{l}\text { Walaupun perusahaan } \\
\text { menghilangkan pemborosan } \\
\text { tersebut,namun itu tidak } \\
\text { meningkatkan nilai produk akhir }\end{array}$ & 0,441 \\
$\begin{array}{l}\text { Pemborosan tersebut akan } \\
\text { menimbulkan lebih banyak } \\
\text { pemborosan lain di masa } \\
\text { mendatang }\end{array}$ & 0,481 \\
$\begin{array}{l}\text { Tidak ada gunanya mencoba } \\
\text { menemukan penyebab } \\
\text { pemborosan tersebut untuk } \\
\text { kemudian menghilangkannya } \\
\text { Saya mempunyai banyak ide } \\
\text { untuk menghilangkan pemborosan } \\
\text { ini dan menemukan penyebabnya }\end{array}$ & 0,027 \\
\hline \multicolumn{1}{|c|}{ Nilai probabitas } & 0,054 \\
\hline
\end{tabular}

Nilai probabilitas semua variabel yang ada dalam faktor 1 yang ditunjukkan oleh angka Asymp. Sig. (2-tailed) adalah > 0,025. Ini berarti responden menerima bahwa aktivitas tidak bernilai tambah atau pemborosan harus dihilangkan.

Dengan cara yang sama seperti tabel diatas dan dengan perhitungan dengan program SPSS 13.0, didapat rangkuman hasil uji Runs masing-masing factor berikutnya adalah sebagai berikut:

1. Hasil uji Runs faktor 2 .

Nilai probabilitas yang ditunjukkan oleh angka Asymp. Sig. (2-tailed) 3 variabel pertama yang ada dalam faktor 2 adalah > 0,025. Ini berarti $\mathrm{H}_{0}$ diterima. Namun tidak demikian pada variabel keempat yang nilai probabilitasnya $<0,05$ menyebabkan keputusan untuk menolak $\mathrm{H}_{0}$. Ini berarti walaupun responden yakin bahwa mereka, bawahannya maupun teman satu timnya bisa membantu perusahaan untuk mengurangi pemborosan tersebut namun mereka belum bisa yakin bahwa tindakan mereka nantinya akan membahayakan posisinya di Perusahaan atau tidak.

2. Hasil Uji Runs Faktor 3.

Nilai probabilitas yang ditunjukkan oleh angka Asymp. Sig. (2-tailed) semua variabel yang ada dalam faktor 3 adalah > 0,025 . Ini berarti bahwa responden setuju bahwa menambah nilai akhir terhadap pelanggan adalah perhatian utama dan akan meminimalkan pemborosan sehingga pertimbangan sistematis diperlukan untuk menghilangkan pemborosan karena pemborosan tersebut akan mengurangu keuntungan perusahaan yang cukup besar.

3. Hasil Uji Runs Faktor 4.

Responden menyadari hadirnya pemborosan, dan menyadari bahwa peningkatan terus-menerus pada setiap proses atau aktivitasnya di organisasi atau lapangan dapat mengurangi pemborosan tersebut, tetapi responden cenderung ingin melakukannya bersama-sama tim kerjanya atau jika Perusahaan mengkehendaki semua karyawannya harus melakukan peningkatan bukan dimulai dari dirisendiri. Ini berarti mentalitas kaizen para praktisi konstruksi jasa di Denpasar masih kurang.

4. Hasil Uji Runs Faktor 5.

Dari tabel dapat dilihat secara umum Perusahaan jasa konstruksi di Denpasar tidak atau setidaknya belum bersedia untuk melakukan perbaikan terusmenerus. Profit atau keuntungan masih menjadi prioritas utama bukan kualitas, dan budaya untuk mengatakan ada kesalahan masih melekat, ini mungkin dikarenakan mereka masih takut jika tindakannya akan membahayakan posisinya di Perusahaan.

Value Stream Mapping proses logistik proyek pada kontraktor bersertifikasi ISO 9000

Dilihat dari peta aliran proses logistik pada kontraktor tersebut bahwa waktu siklus (Cycle Time) dari material tersebut dipesan hingga sampai ke tangan pelanggan hanya 15 menit yang merupakan value added activity dari proses logistik itu sendiri. Selebihnya sebanyak 3 hari, 63 menit merupakan waktu tenggang (Lead Time) yang merupakan aktivitas yang tidak bernilai tambah dari aktivitas logistik dan merupakan pemborosan. Aktivitas tersebut antara lain, menunggu 
persetujuan atasan, transportasi, menunggu proses order yang masih dikerjakan secara manual dan cacat produk pada saat seleksi material.

\section{Value Stream Mapping proses logistik proyek pada kontraktor tidak bersertifikasi ISO 9000}

Pada kontraktor tidak bersertifikasi ISO 9000 peta aliran proses logistiknya mempunyai waktu siklus (Cycle Time) dari material tersebut dipesan hingga sampai ke tangan pelanggan hanya 16 menit yang merupakan value added activity dari proses logistik itu sendiri. Selebihnya sebanyak 50 jam merupakan waktu tenggang (Lead Time) yang merupakan aktivitas yang tidak bernilai tambah dari aktivitas logistik dan merupakan pemborosan. Aktivitas tersebut antara lain, transportasi, menunggu proses order yang masih dikerjakan secara manual dan cacat produk pada saat seleksi material.

\section{Future Value Stream Mapping Proses Logistik proyek}

Pada pemetaan aliran nilai ini, Penulis mengubah proses order secara manual dengan memanfaatkan teknologi informasi yang mudah digunakan oleh pihak lapangan dan pengiriman dokumen-dokumen tersebut dilakukan lewat e-mail ke bagian logistik sehingga penyampaian informasi dapat dilakukan lebih cepat.

Selanjutnya untuk efektivitas sumber daya, peran logistik dan pembelian (purchasing) dapat digabung dan diberikan Signal Kanban di bagian ini. Artinya pihak direksi harus memberikan tanggung jawab kepada pihak logistik/pembelian untuk membuat keputusan apakah material yang diperlukan di lapangan harus diambil dari gudang atau dibeli dari pemasok tertentu dengan jumlah dan spesifikasi sesuai yang direncanakan.

Pada awal aliran proses digunakan alat "supermarket" untuk membuat stok yang aman, kemudian alat "supermarket" lainnya digunakan di akhir aliran. Selama proses tersebut digunakan alat Lean yaitu Kanban. Ada dua tipe kanban yang digunakan disini yaitu: withdrawal kanban dan production kanban. Ketika bagian logistik menerima order dari pihak lapangan, bagian logistik mengirimkan spesifikasi order ke bagian pengiriman, material akan diambil dan dikirim dari supermarket dan mengirimkannya. Ketika material diambil dari supermarket, kanban kembali mengirimkan sinyal kepada bagian penerimaan dan seleksi untuk menarik material dari supermarket sehingga kanban di bagian tersebut akan mengirimkan sinyal ke supplier untuk mengisi kembali material yang ada di supermarket.

\section{SIMPULAN DAN SARAN} Simpulan

1. Dari hasil penelitian didapatkan ada tujuh jenis aktivitas pemborosan yang sering terjadi pada proses logistik proyek konstruksi di Denpasar dan sebabnya. Pertama, aktivitas inspeksi di lapangan karena pekerja tersebut kurang terampil. Kedua, kontraktor membeli satu jenis barang pada pemasok yang berbeda karena kualitas barang yang diberikan pemasok tidak sesuai dengan spesifikasi yang diinginkan, Ketiga, pelaksana yang menunggu instruksi kerja karena prosedur dari owner yang mengharuskan demikian. Keempat, pemasok atau bagian logistik terlambat mengirim material karena proses pengangkutan dan distribusi yang lambat. Kelima, pekerja memerlukan persetujuan atau tanda tangan tambahan dari atasannya karena birokrasi sistem dari perusahaan tersebut sehingga prosedur kerja atau proses lainnya berbelit-belit. Keenam, pekerja sering memerlukan klarifikasi kepada atasannya terhadap suatu tindakan atau perintah karena informasi yang diberikan atasannya tersebut tidak jelas. Dan yang terakhir pekerja baik di kantor maupun di lapangan yang menunggu instruksi kerja dari atasan karena prosedur kerja perusahaan yang juga mengharuskan demikian.

2. Perusahaan dan praktisi jasa konstruksi di Denpasar mempunyai persepsi positif terhadap prinsip Lean Construction sebagai sebuah pilihan strategis dan filosofi baru dalam dunia konstruksi. Mereka setuju bahwa aktivitas tidak bernilai tambah atau pemborosan harus dihilangkan karena pemborosan tersebut akan mengurangi keuntungan perusahaan yang cukup besar. Mereka menyadari bahwa peningkatan terus-menerus pada setiap proses atau aktivitasnya baik di organisasi maupun di lapangan dapat mengurangi pemborosan tersebut, tetapi mereka cenderung ingin melakukannya bersama-sama tim kerjanya bukan dimulai dari diri-sendiri. Ini berarti mentalitas kaizen para praktisi konstruksi jasa di Denpasar masih kurang atau mereka belum bersedia untuk melakukan 
perbaikan terus-menerus yang dimulai dari dirinya sendiri. Profit atau keuntungan masih menjadi prioritas utama bagi perusahaan bukan kualitas

3. Ada beberapa aktivitas tidak bernilai tambah yang terjadi sepanjang value stream logistik proyek konstruksi. Aktivitas tersebut antara lain, menunggu persetujuan atasan, transportasi, menunggu proses order yang masih dikerjakan secara manual dan cacat produk pada saat seleksi material. Aktivitas ini dapat diminimalkan atau dihilangkan dengan alat-alat Lean seperti penggunaan Kanban (signal kanban, withdrawal kanban, production kanban) dan supermarket pada proses logistik tersebut. Otomisasi proses menggunakan teknologi informasi juga diperlukan agar prosesnya menjadi lebih sederhana dan cepat.

\section{Saran}

Dengan teridentifikasinya pemborosan yang sering terjadi pada logistik proyek dan menemukan penyebabnya maka penting bagi praktisi jasa konstruksi untuk lebih memfokuskan untuk meminimalisasi atau menghilangkan pemborosan tersebut dengan tidak mengabaikan pemborosan lain yang mungkin saja terjadi di area lain selain logistik dengan cara menyederhanakan prosedur dan proses agar tidak berbelit-belit dan jika diperlukan membuat prosedur operasi standar, memberikan pelatihan atau keterampilan yang cukup dan baik kepada tenaga kerja agar mereka lebih mandiri, menggunakan teknologi informasi untuk kemudahan penyampaian laporan dan transaksi lain, mengadakan kontrak jangka panjang dengan pemasok dan pelanggan internal sehingga mereka bisa memberikan barang atau material tepat waktu, tepat jumlah dan sesuai dengan spesifikasi yang diinginkan.

\section{DAFTAR PUSTAKA}

Ballard, G. 2001. The Lean Project Delivery System: An Update. Lean Construction Journal 2001: pp. 1-19. Cited at: http://www.leanconstructionjournal.org

Gaspersz, V. 2006. Continous Cost Reduction Through Lean-Sigma Approach, Gramedia Pustaka Utama, Jakarta.

Gaspersz, V. 2007. Lean Six Sigma For Manufacturing and Service Industries, Gramedia Pustaka Utama, Jakarta.
Gitosudarmo, I dan Mulyono, A. 1998. Manajemen Bisnis Logistik, BPFE, Yogyakarta.

Gustavsson, J dan Marzec, C. 2007. Value Stream Mapping-A Case Study of Construction Supply Chain of Prefabricated Massive Timber Floor Element. Master Thesis Växjö Universitet, Sweden. Cited at http://www.vxu.se/

Koskela, L. 1992. Application of the New Production Philosophy to Construction. Technical Report No.72. Department of Civil Engineering Stanford University. Cited http://www.leanconstructionjournal.org

Peterka, P. 2009. Step by Step Guide to Value Stream Mapping. On-line article cited at http://www.bizbods.com/value_stream mapping

Pranoto, B. 2009. Pemborosan Sektor Konstruksi Mencapai 59 Persen. On-line article cited 2009 September 23. Available from: URL: http://www.tempointeraktif.com

Priyatno, D. 2009. 5 Jam Belajar Olah Data dengan SPSS 17, Penerbit Andi, Yogyakarta.

Render, B dan Heizer,J. 2001. Prinsip-Prinsip Manajemen Operasi, Salemba Empat, Jakarta

Senaratne, S dan Wijesiri, D, 2008. Lean Construction as a Strategic Option: Testing its Suitability and Acceptability in Srilanka, Lean Construction Journal 2008: pp.34-48 cited at http://www.leanconstructionjournal.org

Silva,F.B dan Cardoso,F.F, 1999. Applicability of Logistics Management in Lean Construction: A Case Study Approach in Brazilian Building Companies, University of California, Barkeley,CA,USA. Proceedings IGLC-7 cited at http://www.leanconstructionjournal.org

Sugiyono. 2011. Statistik Nonparametris untuk Penelitian. Penerbit Alfabeta. Bandung.

Usman, H dan Akbar P.S. 2006. Pengantar Statistika Edisi Kedua. Penerbit Bumi Aksara. Jakarta. 